\title{
The effect of the ethanol extract from the Dracontium spruceanum rhizome on hematologic and biochemical profiles and performance parameters of broiler chickens
}

\author{
Daniel Paredes-López; Rizal Robles-Huaynate; Darío Mendoza-Isla; Clarita \\ Mendoza-Pérez; Hugo Saavedra-Rodríguez
}

Departamento de Ciencia Animal, Universidad Nacional Agraria de la Selva, Carretera Central Km 1.21, Po Box 156, Tingo María, Peru.

Received August 10, 2017. Accepted September 4, 2018.

\begin{abstract}
The objective of the research was to evaluate the antioxidant capacity and effect of the ethanol extract from the Dracontium spruceanum rhizome (EERDs) on the blood, biochemical and productive parameters of chickens. To do so, ninety, male, Cobb 500 broiler chickens were used. Once the dehydrated extract was obtained, it was place in the drinking water at concentrations of $0.0,0.35$ and $0.70 \mathrm{mg} / \mathrm{mL}$ of EERDs. The birds were distributed into three treatments, five repetitions and each repetition had six chickens. The variance analysis was done with the statistical program InfoStat and the averages of the treatments were analyzed with the 5\% Tukey test. The results showed that chickens that consumed drinking water with EERDs presented $(p<0.05)$ greater concentrations of hematocrit, hemoglobin and erythrocytes; meanwhile, the serum protein and the glucose did not change $(p>0.05)$. The daily food consumption diminished $(p<0.05)$ and the DWG and FRC were not influenced ( $p>0.05$ ) by the consumption of EERDs in the drinking water. It is concluded that the consumption of EERDs by broiler chickens from 1 to 35 days of age produces greater concentrations of the levels of red blood cells and diminishes the feed intake.
\end{abstract}

Keywords: Dracontium spruceanum; hematocrit; productive performance; antioxidant capacity.

\section{Introduction}

The intensive production of domestic animals, conditions them to stressful oxidative processes, due to the handling conditions such as the confinement, the breeding density, productive stage, etc. (HuertaJimenez et al., 2005; Koknaroglu and Akunal, 2013).

Oxidative stress occurs in all animal species, above all, in those with early growth, like the broiler chicken, which due to its physiological characteristics and intense metabolic activity, is permanently producing oxidative substances (DrÖge, 2002). To overcome this demand, the first line of action of the organism is to resort to its endogenous antioxidant reserves and the use of nutrients to alleviate the negative effects.

To improve the adverse effects of oxidative stress and the productive indices, traditionally, we resort to the use of pharmaceuticals which, on one hand, develop microorganism's resistant to the drugs and on the other hand, generate residuals in the derived products that could have collateral effects for the consumer (Bistoletti et. al., 2011; Sakai et al., 2016). Due to this, at present the industry is introducing natural antioxidants to eliminate the factors that negatively affect production (Jahanian and Mirfendereski, 2015; Boostani et al., 2015; Gerasopoulos et al., 2015; Soltani et al., 2016).

Dracontium spruceanum is a plant in the Peruvian Amazon which is characterized by its antioxidant and immunomodulatory properties (Giovannini and Howes 2017; Benavides et al., 2009; Napolitano et al., 2011; Lovera et al., 2006); due to this, its 
use in the feeding of broiler chickens could improve their well-being and health. The objective was to determine the effect of the ethanol extract from the Dracontium spruceanum rhizome in the well-being and health of broiler chickens under an intensive rearing system, through the evaluation of the in vitro antioxidant activity, blood profiles and productive parameters.

\section{Materials and methods Obtaining the Ethanol Extract from the Dracontium spruceanum Rhizome}

For this, a $200 \mathrm{~g}$ sample of the rhizome, dried and crushed, was placed in a jar, later ethanol was added at $75 \%$ to reach one liter and it was left macerating for fortyeight hours. Later, the suspension was stirred and filtered with cotton. The filtered substance, containing the extract, was submitted to evaporation of the ethanol, using a rota vapor and finally, finished drying in an oven at $65^{\circ} \mathrm{C}$. The ethanol extract obtained was packaged and stored.

Determining the antioxidant activity in vitro The antioxidant capacity of the ethanolic extract from $D$. spruceanum, was evaluated using the method of sequestering the free radical 1,1 diphenil-2-picrylhidrazyl (DPPH) (100 uM) (Brand-Williams et al., 1994; Sánchez-Moreno, 2002), causing a reaction with $25,75,125,175$ and $250 \mu \mathrm{g} / \mathrm{mL}$ of EERDs; the readings were done in a UV light spectrophotometer and Electron Corporation visual, Genesys -6 model, with a $515 \mathrm{~nm}$ filter, every thirty seconds for a total time of ten minutes.

The percentage of inhibition of the DPPH obtained by each of the concentrations was used to determine the Inhibition Coefficient $\left({ } C_{50}\right)$, which was expressed in $\mu \mathrm{g} / \mathrm{mL}$, indicating the necessary quantity of the aqueous atomized extract from $D$. spruceanum to inhibit, at $50 \%$, the DPPH radical.

\section{Experimental Animals}

The work was done with ninety baby male chickens from the Cobb Vantress 500 breed, with an average weight of $46.11 \pm$ $1.6 \mathrm{~g}$; which were distributed into three treatments, with five repetitions and each repetition with six birds, which were bred under similar handling and feeding conditions. Three balanced diets were formulated, the composition of which was according to the requirements of the breed (Rostagno et al., 2011).

\section{Design and Statistical Analysis}

The hematological profiles were submitted to a completely randomized design CRD with a factorial arrangement of $3 \times 2+1$ (three levels of EERDs $\times 2$ ages +1 control). The productive performance parameters were submitted to a completely randomized design (CRD) with three treatments, five repetitions and each repetition with six chickens. The variance analyses were done with the statistical program InfoStat (Universidad Nacional de Cordova, 2016) and the averages were compared using the Tukey test $(5 \%)$.

\section{Results and discussion}

Antioxidant Activity of the Ethanol Extract from the Dracontium spruceanum Rhizome The inhibition capacity was related to the concentration of EERDs, with T1 (250 $\mu \mathrm{g} / \mathrm{mL}$ ) showing the greatest free radical inhibition capacity $(p<0.05)$ (Table 1$)$.

Table 1

Effect of the Ethanol Extract from the Dracontium spruceanum

Rhizome (EERDs) on the in vitro inhibition of DPPH

\begin{tabular}{lcc}
\hline $\begin{array}{l}\text { Concentration de } \\
\text { EERDs }\end{array}$ & $\begin{array}{c}\text { Absorbance } \\
515 \mathrm{~nm}\end{array}$ & $\begin{array}{c}\text { Inhibition } \\
(\%)\end{array}$ \\
\hline T1: $250 \mu \mathrm{g} / \mathrm{mL}$ & $0.260 \pm 0.01$ & $71.92^{\mathrm{e}}$ \\
$\mathrm{T} 2: 175 \mu \mathrm{g} / \mathrm{mL}$ & $0.403 \pm 0.01$ & $56.56^{\mathrm{d}}$ \\
$\mathrm{T} 3: 125 \mu \mathrm{g} / \mathrm{mL}$ & $0.577 \pm 0.01$ & $37.79^{\mathrm{C}}$ \\
$\mathrm{T} 4: 75 \mu \mathrm{g} / \mathrm{mL}$ & $0.752 \pm 0.01$ & $18.88^{\mathrm{b}}$ \\
T5: $25 \mu \mathrm{g} / \mathrm{mL}$ & $0.858 \pm 0.01$ & $7.41^{\mathrm{a}}$ \\
\hline $\begin{array}{l}\text { Different letters in the } \\
\text { differences (SNK 5\%). }\end{array}$ & &
\end{tabular}

By the linear equation, it was determined that he concentration of EERDs required to inhibit the DPPH at $50 \%$ was $164.37 \mu \mathrm{g} / \mathrm{mL}$ (Figure 1). The treatments with $25 \mu \mathrm{g} / \mathrm{mL}$ and $250 \mu \mathrm{g} / \mathrm{mL}$ generate an inhibition of 7.41 and $71.92 \%$, respectively; showing that the greater the concentration of EERDs, the greater the inhibition of the DPPH radical. Velandia (2009), did a test on the antioxidant activities, with fraction and extracts from Dracontium croatti, at different concentrations $(1-100 \mu \mathrm{g} / \mathrm{ml})$, with butanol, on the retention effect of the DPPH; obtaining an $\mathrm{IC}_{50}$ with $25.12 \mu \mathrm{g} / \mathrm{ml}$ of the extract. This difference could be associated to the specie of Dracontium.

The antioxidant activity of Dracontium spruceanum could be associated to the presence of highly unsaturated nuclei such as polyphenols, flavonoids and quinones (Rivera, 2012), as well as to the presence of aromatic compounds like sterols, triterpenoids and alkaloids (Rengifo, 2007). In a similar study with an aqueous atomized extract from Uncaria tomentosa, it was found that the inhibition of the DPPH radical was $88.17 \%$ with $250 \mu \mathrm{g} / \mathrm{ml}$ of the extract (Sandoval, 2012). 
Table 2

Hematological and biochemical profiles of broiler chickens under the effect of EERDs in the drinking water at different age

\begin{tabular}{|c|c|c|c|c|c|}
\hline Factors & $\begin{array}{c}\text { Hematocrit } \\
(\%)\end{array}$ & Hemoglobin $(g / d L)$ & $\begin{array}{l}\text { Erythrocytes } \\
\text { (x106/uL) }\end{array}$ & $\begin{array}{l}\text { Serum Protein } \\
(\mathrm{g} / \mathrm{dL})\end{array}$ & Glucose (g/dL) \\
\hline $\begin{array}{l}\text { EERDs Age } \\
\text { ExA }\end{array}$ & $\begin{array}{l}0.027 \\
0.011 \\
0.002 \\
\end{array}$ & $\begin{array}{l}0.008 \\
0.001 \\
0.032\end{array}$ & $\begin{array}{l}0.012 \\
0.001 \\
0.049\end{array}$ & $\begin{array}{l}0.978 \\
0.007 \\
0.411\end{array}$ & $\begin{array}{l}0.111 \\
0.012 \\
0.756\end{array}$ \\
\hline cv (\%) & 9.57 & 19.35 & 21.83 & 18.78 & 6.47 \\
\hline $\begin{array}{l}\text { Level of EERDs } \\
0.00 \mathrm{mg} / \mathrm{mL} \\
0.35 \mathrm{mg} / \mathrm{mL} \\
0.70 \mathrm{mg} / \mathrm{mL}\end{array}$ & $\begin{array}{l}24.84 b \\
25.53 a \\
26.54 a\end{array}$ & $\begin{array}{l}8.12 b \\
8.98 b \\
10.39 a\end{array}$ & $\begin{array}{l}1.28 b \\
1.72 a \\
1.89 a\end{array}$ & $\begin{array}{l}2.33 \\
2.29 \\
2.27\end{array}$ & $\begin{array}{l}195.0 \\
205.0 \\
200.0\end{array}$ \\
\hline \multicolumn{6}{|l|}{ Age in Days } \\
\hline $\begin{array}{l}1 \text { day } \\
14 \text { days } \\
28 \text { days }\end{array}$ & $\begin{array}{l}25.73 a b \\
26.37 a \\
24.61 b\end{array}$ & $\begin{array}{l}6.87 \mathrm{c} \\
8.31 \mathrm{~b} \\
10.44 \mathrm{a}\end{array}$ & $\begin{array}{l}0.743 c \\
1.36 b \\
2.08 a\end{array}$ & $\begin{array}{l}2.49 a \\
2.44 a \\
2.10 b\end{array}$ & $\begin{array}{l}192.0 \mathrm{~b} \\
196.0 \mathrm{~b} \\
206.0 \mathrm{a}\end{array}$ \\
\hline
\end{tabular}

abc: Different letters in the same column indicate statistical differences (SNK 5\%). EERDs: Ethanol extract from the Dracontium spruceanum rhizome.

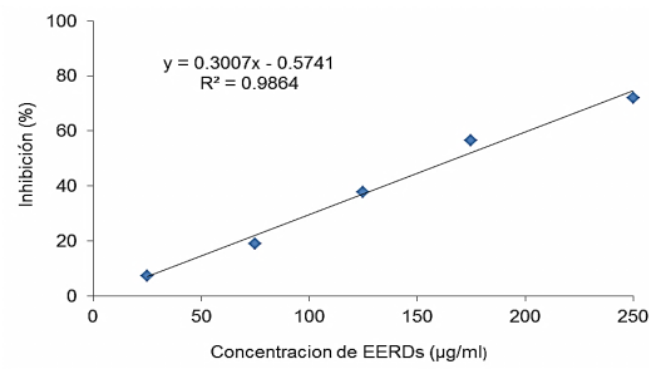

Figure 1. Inhibition coefficient $\left(\mathrm{IC}_{50}\right)$ of DPPH due to the action of the ethanol extract from the Dracontium spruceanum rhizome (EERDs).

\section{Hematological and Biochemical Profiles}

The hematocrit, hemoglobin and total erythrocyte profiles of the experimental chickens increased as the level of EERDs in the drinking water $(p<0.05)$ increased. However, the serum protein and glucose profiles were similar between treatments $(p$ $>0.05$ ) (Table 2).

The hematocrit increased at twenty-eight days old $(p<0.05)$ as the level of the EERDs increased in the drinking water; these results resemble the study by Sandoval (2012), who reported a progressive increase in the percentage of hematocrit in broiler chickens every time the ${ } \mathrm{C}_{50}$ from the aqueous atomized extract of cat's claw was increased in the drinking water.

The level of hemoglobin increased at fourteen days of age $(p<0.05)$ as the levels of EERDs increased in the drinking water (Tables 2 and 4). This also increased with the increase in the birds age from the control group and in the group with 0.35 $\mathrm{mg} / \mathrm{mL}$ of EERDs $(p<0.05)$. These results are similar to those reported by Sandoval (2012), meanwhile, Reátegui-Inga et al., (2012) reported an increase in hemoglobin at forty-eight days old.
This profile also increased as an effect of the age of chickens up to fourteen days only in the control group, $(p<0.05)$ (Tables 2 and 3). This could be associated to the fact that the antioxidant effect of the EERDs on the cells allows for a lengthening of the life of the erythrocytes, covering up the effect of age on erythrocytes life span in the treatment groups chickens; contrasting with the physiological patterns which are characterized by a progressive increase in the level of hematocrit each time that the chickens increase in age (Vásquez et al., 2012).

\section{Table 3}

Hematocrit profile (\%) under the effect of EERDs level in the drinking water and age of Chickens

\begin{tabular}{clll}
\hline Level of & \multicolumn{3}{c}{ Age of Chickens } \\
\cline { 2 - 4 } EERDs & 1 day & 14 days & 28 days \\
\cline { 2 - 4 } $0.00 \mathrm{mg} / \mathrm{m}$ & $25.73 \mathrm{~A}$ & $26.90 \mathrm{~A}$ & $21.90 \mathrm{Bb}$ \\
$0.35 \mathrm{mg} / \mathrm{m}$ & & 25.61 & $25.44 \mathrm{a}$ \\
$0.70 \mathrm{mg} / \mathrm{mL}$ & & 26.58 & $26.50 \mathrm{a}$ \\
\hline
\end{tabular}
lowercase letters in each column indicate statistical differences (SNK 5\%). EERDs: Ethanol extract from Dracontium spruceanum rhizome.

Table 4

Hemoglobin profile $(\mathrm{g} / \mathrm{dL})$ under the effect of EERDs level in the drinking water and age of Chickens

\begin{tabular}{cccc}
\hline Level of & \multicolumn{3}{c}{ Age of Chickens } \\
\cline { 2 - 4 } EERDs & 1 day & 14 days & 28 days \\
\cline { 2 - 4 } $0.00 \mathrm{mg} / \mathrm{m}$ & $6.87 \mathrm{~B}$ & $6.99 \mathrm{Bb}$ & $10.10 \mathrm{~A}$ \\
$0.35 \mathrm{mg} / \mathrm{m}$ & & $7.82 \mathrm{Bb}$ & $10.15 \mathrm{~A}$ \\
$0.70 \mathrm{mg} / \mathrm{mL}$ & & $10.12 \mathrm{a}$ & 10.67 \\
\hline $\mathrm{AB}$, ab: Different capitalized & letters in the same row and
\end{tabular}

AB, ab: Different capitalized letters in the same row and lowercase letters in each column indicate statistical differences (SNK 5\%). EERDs: Ethanol extract from the Dracontium spruceanum rhizome.

The number of erythrocytes in broiler chickens increased $(p<0.05)$ as the dose of the EERDs in the drinking water increased at 28 days (Tables 2 and 5 ). The level of erythrocytes also increased with the increase of the age, as much in the control group as in the groups with 0.35 and 0.70 $\mathrm{mg} / \mathrm{mL}$ of EERDs $(p<0.05)$. 
Table 5

Total Erythrocytes $\left(\times 10^{6} / \mu \mathrm{L}\right)$ under the effect of EERDs levels in the drinking water and age of Chickens

\begin{tabular}{clll}
\hline Level of & \multicolumn{3}{c}{ Age of Chickens } \\
\cline { 2 - 4 } EERDs & 1 day & 14 days & 28 days \\
\hline $0.00 \mathrm{mg} / \mathrm{m}$ & $0.743 \mathrm{C}$ & $1.29 \mathrm{~B}$ & $1.82 \mathrm{Ab}$ \\
$0.35 \mathrm{mg} / \mathrm{m}$ & & $1.42 \mathrm{~B}$ & $2.02 \mathrm{Ab}$ \\
$0.70 \mathrm{mg} / \mathrm{mL}$ & & $1.38 \mathrm{~B}$ & $2.41 \mathrm{Aa}$ \\
\hline
\end{tabular}

AB, ab: Different capital letters in the same row and lowercase letters in each column indicate statistical differences (SNK 5\%). EERDs: Ethanol extract from the Dracontium spruceanum rhizome.

The level of hematocrit, hemoglobin and the number of erythrocytes of broiler chickens are within the normal values (Reece, 2015).

The increase in hemoglobin, hematocrit and total erythrocytes as the EERDs increases may be related with those described for Uncaria tomentosa. The numerous groups of compounds present in this plant have protective effects on erythrocytes and diminish the levels of hemoglobin oxidation and the lipid peroxidation; as well as lowering the levels of ROS and hemolysis provoked by 2-4 dichlorophenol in human erythrocytes (Bors et al., 2011; Bucowska et al., 2012).

The polyphenols, principal components of the Uncaria tomentosa extracts, could act, not just sequestrating free radicals and inhibitors of lipid peroxidation, but also have the capacity to interact directly with biological membranes, causing them to be more resistant to oxidative alterations (Dreifus et al., 2010). These same mechanisms permit human erythrocytes to induce an increase in membrane thickness, followed by an increase in size and morphological variation (Bors et al., 2012). In the present study, it was found that an interaction exists, between the dose of EERDs in the drinking water and the age of chickens, on the levels of hematocrit, hemoglobin and erythrocytes $(p<0.05)$ (Tables 2, 3, 4 and 5). The results show that the levels of hematocrit, hemoglobin and total erythrocytes, in general, increase with the age increase and the increase in the level of EERDs, which could be associated to physiological mechanisms of increase in oxygen demand by the muscular mass for metabolism (Skovgaard et al., 2010) and antioxidant and immunomodulatory activity of Dracontium (Giovannini and Howes, 2017; Benavides et al., 2009; Napolitano et al., 2011), similar to those produced by $U$. tomentosa (Vielma, et al., 2014; Wagner, et al., 1985).

The age of chickens influenced $(p<0.05)$ the levels of serum protein and glucose, denoting that chickens at one and fourteenday old presented a greater concentration of serum protein $(p<0.05)$ than the chic- kens at twenty-eight days old (Table 2). These results contrast with serum protein levels produced by the physiological mechanisms (Eckersall, 2008); different results from those were reported by Sandoval (2012). On the contrary, the glucose resulted at a greater level in the chickens of twenty-eight days old than those at one and fourteen days old ( $p<$ 0.05). This data contrasts the results of Gonzáles et al. (2001), who showed a lowering of the serum glucose level in broiler chickens as age increased.

\section{Productive Parameters}

The daily feed intake (DFI) diminished as a result of the EERDs increase in the drinking water $(p<0.05)$ during the finishing phase (22-35 days) and during the total rearing phase (1-35 days) (Table 6). However, the daily weight gain (DWG) and the feed rate conversion (FRC) of the male broiler chickens during the initial, growth, and finishing phases and the total period, were not influenced by the level of EERDs in the different productive phases of the broiler chickens $(p>0.05)$.

Table 6

Productive parameters of broiler chickens under the effect of different levels of EERDs

\begin{tabular}{llllll}
\hline Initial Phase: 1 to 7 days old \\
\hline Trat. & IW & FW & DWG & DFI & FRC \\
\hline $0.00 \mathrm{mg} / \mathrm{mL}$ & 46.00 & 212.00 & 28.00 & 28.00 & 1.04 \\
$0.35 \mathrm{mg} / \mathrm{mL}$ & 45.00 & 207.00 & 27.00 & 27.00 & 1.03 \\
$0.70 \mathrm{mg} / \mathrm{mL}$ & 47.00 & 213.00 & 28.00 & 29.00 & 1.04 \\
\hline p-value & 0.15 & 0.52 & 0.52 & 0.84 & 0.99 \\
\hline cv (\%) & 3.10 & 3.57 & 4.57 & 12.67 & 3.19 \\
\hline Growth Phase: 8 to 21 days old & & & \\
\hline $0.00 \mathrm{mg} / \mathrm{mL}$ & 212.00 & 1028.00 & 58.00 & 97.00 & 1.66 \\
$0.35 \mathrm{mg} / \mathrm{mL}$ & 207.00 & 1029.00 & 59.00 & 96.00 & 1.64 \\
$0.70 \mathrm{mg} / \mathrm{mL}$ & 213.00 & 994.00 & 56.00 & 94.00 & 1.69 \\
\hline p-value & 0.52 & 0.26 & 0.26 & 0.38 & 0.78 \\
\hline cv (\%) & 3.57 & 3.33 & 4.20 & 3.19 & 6.63 \\
\hline
\end{tabular}

Finishing Phase: 22 to 35 days old

$0.00 \mathrm{mg} / \mathrm{mL} \quad 1028.00 \quad 2242.00 \quad 87.00 \quad 159.00 \mathrm{a} \quad 1.83$ $0.35 \mathrm{mg} / \mathrm{mL} 1029.00 \quad 2193.00 \quad 84.00156 .00 \mathrm{ab} \quad 1.87$ $0.70 \mathrm{mg} / \mathrm{mL} 994.00 \quad 2227.00 \quad 86.00 \quad 155.00$ b 1.80

\begin{tabular}{lllllll}
\hline$p$-value & 0.26 & 0.58 & 0.58 & 0.042 & 0.62 \\
\hline cv (\%) & 3.33 & 3.33 & 6.15 & 1.62 & 6.10
\end{tabular}

Total Period: 1 to 35 days old

\begin{tabular}{llllll}
\hline $0.00 \mathrm{mg} / \mathrm{Ml}$ & 46.00 & 2247.00 & 63.00 & $108.00 \mathrm{a}$ & 1.72
\end{tabular} $0.35 \mathrm{mg} / \mathrm{mL} \quad 45.00 \quad 2170.00 \quad 61.00 \quad 107.00 \mathrm{ab} \quad 1.76$ $0.70 \mathrm{mg} / \mathrm{mL} \quad 47.00 \quad 2245.00 \quad 63.00 \quad 105.00 \mathrm{~b} \quad 1.68$

\begin{tabular}{llllll}
\hline p-value & 0.15 & 0.29 & 0.29 & 0.039 & 0.39 \\
\hline
\end{tabular}

\begin{tabular}{llllll}
\hline cv (\%) & 3.10 & 3.51 & 3.58 & 1.61 & 4.55
\end{tabular}

a,b: Different letters in the same column indicate statistical differences (SNK 5\%). EERDs: Ethanol extract from the Dracontium spruceanum rhizome. IW: initial weight, FW: final weight, DWG: daily weight gain, DFI: daily feed intake, FRC: feed rate conversion. 
These results could be correlated to the toxic effects of certain plants with similar nutraceutical characteristics to Dracontium, as is the case of $U$. tomentosa, for which toxic effects have been found in rats, mice and fish (Méndez et al., 2014; Ibrahim et al., 2009; Cala and Kochenborger, 2015), and associated with the initial phase of chickens (Sandoval, 2012).

Notwithstanding, the lack of effect of the DFI lowering on the weight gain of chickens could also be attributed to the fact that Dracontium possesses similar characteristics to those reported for $U$. Tomentosa, which improve the length of the intestinal villi and as a result the improvement in the absorption of nutrients (Yunis-Aguinaga et al., 2015); thus, counteracting the potential toxic effects attributed, in the same manner, to this plant.

\section{Conclusions}

The ethanol extract of the Dracontium spruceanum rhizome at a concentration of $164.37 \mathrm{ug} / \mathrm{mL}$ inhibited $50 \%$ the DPPH; at the same time, the levels of hematocrit, hemoglobin and total erythrocytes increased, while the daily food consumption decreased and there was no effect on the daily weight gain and food rate conversion in the broilers. Other research to clarify potential toxic effects and promotors of intestinal health from $D$. spruceanum should be done.

\section{References}

Benavides, A.; Napolitano, A.; Bassarello, C.; Carbone, V.; Gazzerro, P.; Malfitano, A.; Saggese, P.; Bifulco, M.; Piacente, S.; Pizza, C. 2009. Oxylipins from Dracontium loretense. J. Nat. Prod. 72 (5): 813-817.

Bistoletti, M.; Moreno, L.; Alvarez, L.; Lanusse, C. 2011. Multiresidue HPLC method to measure benzimidazole anthelmintics in plasma and egg from laying hens. Evaluation of albendazole metabolites residue profiles. Food Chemistry 126: 793-800.

Boostani, A.; Sadegui, A.; Mousavi, S.N.; Chamani, M.; Kashan, N. 2015. Effect of organic, inorganic and nano-Se on growth perfomance, antioxidant capacity, cellular and humoral immune response in broiler chicken exposed to oxidative stress. Livestock science 178: 330-336

Bors, M.; Cisinska, P.; Michalowicz, J.; Wieteska, P.; Gulewicz, K.; Bucouska, B. 2012. Evaluation of the effect of Uncaria tomentosa extract on the size and shape of human erythrocyte (in vitro). Environmental toxicology and pharmacology 233: 127-134.

Brand-Williams, W.; Berset, C.; Cuvelier, M.E. 1994. Use of free radical method to evaluate antioxidant activity. J. Agric. Food Chem. 1234 - 1238.

Bucowska, B.; Bors, M.; Gulewicz, K.; Koter-Michalak, M. 2012. Uncaria tomentosa extracts protects human erythrocytes catalase against induced by 2 , 4-D-Na and its metabolites. Journal of Etnopharmacology 50: 2123-2127.

Cala, D.; Kochenborger, J. 2015. Suplementacao de una-de-gato (Uncaria tomentosa) en dietas para
tilapias-do-Nilo e acará-bandeira (Pterophyllum scalare). Tesis posgrado. Sao paulo. Universidad Estadual Paulista.

Dreifus, A.; Bastos-Pereira, A.; Avila, T.; Da Silva, B.; Rivero, A.; Aguilar, J.; Acco, A. 2010. Antitumoral and antioxidant effects of a hidroalcoholic extract of cat's claw (Uncaria tomentosa) (Willd Ex Roem \& Schult) in an in vivo carcinoma sarcoma model. Journal of Etnopharmacology 130(1): 127-133.

DrÖge, W. 2002. Free radicals in the physiological control of cell function. Physiol. 82: 47-95.

Eckersall, P. 2008. Chapter 5: Proteins, proteomics and dysproteinemias. In: Kaneko, J.J.; Harvey, J.W.; Bruss, M.L. Clinical Biochemsitry of Domestic Animals. 6th Edition, Academic Press. P. 117-155.

Gerasopoulos, K.; Stagos, D.; Kokkas, S.; Petrotos, K.; Kantas, D.; Goulas, P.; Kouretas, D. 2015. Feed supplement with byproducts from olive oil mil wastewater processing increases antioxidant capacity in broilers chicken. Food and Chemical Toxicology 82: 42-49.

Giovannini, P., Howes, M. 2017. Medicinal plants used to treat snakebite in Central America: Review and assessment of scientific evidence. Journal of Ethnopharmacology 199: 240-256.

Gonzáles, F.; Haida, K.; Mahl, D.; Giannesi, G.; Kronbauer, E. 2001. Incidencia de doencas matabólicas em frangos de corte no sul do brasil e uso do perfil bioquímico sanguíneo para seu estudo. Rev. Bras. Cienc. Avic. 3(2): 52-63.

Huerta-Jimenez, M.; Ortega-Cerrilla, M.; Cobos-Peralta, M.; Herrera-Jaro, J.; Diaz-Cruz, A.; GuinzbergPerrusquia, R. 2005. Stress oxidativo y el uso de antioxidantes en animales domésticos. Interciencia 30(12): 728-734.

Ibrahim, K.; Al-Ashban; Al-Sammani, S.A. 2009. A study of the toxicity of cat's claw herbal medicine. Research Journal of Pharmacology 3(3): 52-57

Jahanian, R.; Mirfendereski, E. 2015. Effect of high stocking density on performance, egg quality, and plasma and yolk antioxidant capacity in laying hens supplemented with organic chromium and vitamin C. Livestock Science 177: 117-124.

Koknaroglu, H.; Akunal, T. 2013. Animal welfare: An animal science approach. Meat Science 95: 821-827

Lovera, A.; Bonilla, C.; Hidalgo, J. 2006. Efecto neutralizador del extracto acuoso de Dracontium loretense (Jergón Sacha) sobre la actividad letal del veneno de Bothrops atrox. Rev. Perú Med. Exp. Salud Pública 23(3): 177-181.

Méndez, P.; Ponce, F.; Fraga, D.; Pípole, F.; Perazzo, F.; Hueza, I. 2014. High doses of Uncaria tomentosa (cat's claw) reduces blood glucose levels in rats. Int. J. Pharm and pharm Science 6(2): 410-415.

Napolitano, A.; Benavides, A.; Pizza, C.; Piacente, S. 2011. Qualitative on-line profiling of ceramides and cerebrosides by high performance liquid chromatography coupled with electrospray ionization ion trap tandem mass spectrometry: the case of Dracontium loretense. J. Pharm. Biomed. Anal. 55(1): 23-30.

Reece, W. 2015. The composition and functions of blood. In: Reece, W.O.; Erickson, H.H.; Goff, J.P.; Uemura, E.E. Duckes' Physiology of Domestic Animals 13th Edition, Wiley Blackwell, OX, UK. P. 114-136.

Reátegui-Inga, R.; Paredes-López, D.; Robles-Huaynate, R. 2012. Efecto de diferentes niveles de torta de sacha inchi (Plukenetia volúbilis) sobre el hígado y el perfil bioquímico sanguíneo de pollos de carne. Folia Amazónica 24(2): 131-138.

Rengifo, E. 2007. Las ramas floridas del bosque "Experiencias en el manejo de plantas medicinales amazónicas". Instituto de Investigaciones de la Amazonia Peruana IIAP. Perú. 49p. Disponible en: http://repositorio.iiap.org.pe/bitstream/IIAP/147/2/R engifo_libro_2007.pdf

Rivera, L. 2012. Caracterización fitoquímica, farma céutica, y alimenticia de papa culebrera india (Dracontium spruceanum (Schott), G.H.Zhu, 
Araceae) y sande (Brosinium utile (Kunth) Oken, Moraceae) del Jardín Botánico de Plantas Medicinales del CEA de Corpoamazonia, Mocoa, Putumayo. Bogota, Colombia. $11 \mathrm{pp}$.

Rostagno, H.; Albino, L.; Donzele, J.; Gomes, P.; De Oliveira, R.; Lopez, D.; Ferreira, A.; Barreto, S.; Euclides, R. 2011.Tablas Brasileñas para aves y cerdos. Composición de alimentos y requerimientos nutricionales. 3a Edición. Universidad Federal de Viçosa-Departamento de Zootecnia. 259 pp.

Sakai, N.; Sakai, M.; Mohamad Haron, D.; Yoneda, M; Mohd, M. 2016. Beta agonists residues in cattle, chicken and swine livers at the wet market and the environmental impacts of wastewater from livestock farmers in Selangor state, Malaysia. Chemosphere 165: 183-190.

Sánchez-Moreno, C. 2002. Review: Methods Used to Evaluate the Free Radical Scavenging Activity in Foods and Biological Systems. Food Science and Tecnology International 8(3): 121-137.

Sandoval, C. 2012. Capacidad antioxidante del extracto atomizado de uña de gato (Uncaria tomentosa) y efecto sobre los perfiles bioquímicos sanguíneos, constants hematológicas y parámetros productivos en pollos de carne. Tesis. Pregado. Universidad Nacional Agraria de la Selva. Tingo María. Perú: 77 pp.

Skovgaard, N.; Hicks, J.; Wang, T. 2010. Oxygen uptake and transport in air breathers. In: Nilsson, G.E. Respiratory Physiology of Vertebrates. Cambridge University Press. CB. UK. p. 95-127.

Soltani, M.; Tabeidian, S.; Ghalamkari, G.; Adeljoo, A.; Mohammadrezai, M.; Saheb Fosoul, S. 2016. Effect of dietary extract and dried aereal parts of Rosmarinus officinalis on perfomance, immune response, and total serum antioxidant activity in broiler chicken. Asian Pacific Journal of tropical disease 6(3): 218-222.

Universidad Nacional de Córdova. 2016. Corporation Analytical Service: InfoStat

Vásquez, M.; Cueva, S.; Lira, B.; Ayón, M.; Rodríguez, J.; Angulo, P.; Falcón, N. 2012. Rol del óxido nítrico en la hipertrofia arteriolar pulmonar y ventricular cardiaca derecha en pollos a nivel el mar y expuestos a hipoxia de altura. Rev. Inv. Ve. Perú 23(1): 1-12.

Velandia, D. 2009. Evaluación cicatrizante y caracterización fitoquimica de Dracontium croatii, Tesis Postgrado. Universidad Nacional de Colombia. p 55-56.

Vielma, H.; Hernández, L.; Rodríguez, C.; Rivera, L. 2014. Propiedades inmunomoduladoras de la uña de gato. Planta 9(18):38-40.

Wagner, H.; Kreutzcam, P.; Juric, K. 1985. Alkaloides of Uncaria tomentosa and their phagocytosis increasing effect. Plant. Med. 51: 25-31.

Yunis-Aguinaga, F.; Claudiano, G.; Marcuso, P.F.; Ikefuti, C.; Ortega, G.; Eto, S.; de Cruz, C.; Moraes, L.; Moraes, F.; Fernades, J. 2014. Acute toxicity and determination of active constituent of aqueous extract of Uncaria tomentosa bark on Hyphessobrycon eques. Journal of toxicology ID 412437: 1-5. 